\title{
The Bon, the Bad and the Others
}

\author{
By Christina Stojanova \\ Spring 2008 Issue of KINEMA
}

\section{The Bon, the Bad and the Others: Some Remarks on the Phenomenal Success of Bon Cop, Bad Cop in Quebec}

This article discusses some aspects of the phenomenal box-office success in Quebec of Bon Cop, Bad Cop directed by Eric Canuel, released in 2006.

Let me first refer to some statistics: within nine weeks or so from its release in early August of 2006, Bon Cop, Bad Cop was a few thousand dollars short of equalling the box-office success of Porky's, the all-time Canadian box office success from the early 1980s, a raunchy Florida-set sex-comedy that made 11.2 million in Canada. Ninety percent of the box-office, however, came from the home province ticket sales of Bon Cop, Bad Cop, leaving far behind such recent viewers' darlings as Les Boys from 1997, La grande seduction and Les invasions barbares, both from 2003 and above all, Seraphin, the historical drama from 2002 about "the man and his sin," which had so far held first place as the most popular film in Quebec, grossing 9 million and three hundred thousand dollars. However, Bon Cop, Bad Cop grossed only 1.4 million in the rest of Canada, a gain off-set to a considerable extent by the expensive promotional campaign run in the ROC. The box-office results outside Quebec were the strongest in Toronto and Ottawa, but the film found little support outside of Ontario. In any case, even at 1.4 million dollars, the bilingual action comedy shot in Montreal is a feat, achieved by few English Canadian films and even fewer Québecois films in English Canada.

But what is this film all about? The allusions to the Lethal Weapon, Rush Hour and other famous Hollywood sequels about hilariously mismatched policemen are more than incidental - they are outright deliberate. The premise of the film, devised by its star Patrick Huard, mobilizes what Leo Braudy calls the genre expectations of the audience, bringing together two polar opposite police officers from Ontario and Quebec to work on a hockey-related murder investigation after a body is found splayed over the welcome billboard sign at the very border between the two provinces - with its ass in Ontario and its heart in Quebec - as the respective police officers remark in their very first exchange, thus setting the tone of the film. One of the title characters is Martin Ward, played by the Stratford theatre star Colm Feore, also known to film and TV viewers for his interpretation of the acclaimed pianist in Thirty-Two Short Films about Glenn Gould and of Trudeau in the eponymous mini-series. Feore is the uptight, turtleneck-wearing bilingual Ontario law enforcer, a graduate of the prestigious Upper Canada college. His opposite number is Patrick Huard's David Bouchard, an explosive, chain-smoking Québecois cop who cheerfully breaks the rules and drives a jalopy. Patrick Huard, whose breakthrough film was Les Boys, is among the few uncontested male stars of Quebec cinema, and teenage girls' heart throb. Throughout the film, it is Huard's Bouchard and the Québecois characters that steal the show, literally, especially Louis-Jose Houd, a manic blast as a motor-mouthed coroner, brought almost to paroxysm by how the English pronounce "tattoo." Pierre Lebeau as Le Boeuf, Bouchard's nearapoplectic boss, whose carefully mouthed correct English words make no sense in a sentence, invariably brings in the second level of the film's meaning, always there to challenge and deconstruct the first and remind the audience that this is an equal opportunity mockery in action.

The success of the film is prompted to a large extent by the genuine chemistry between Colm Feore and Patrick Huard and the extremely skilfully handled bilingual dialogue (indeed, the filmmakers take an exquisite pride in the fact that this is actually the first French-English bilingual film. It however leaves one wondering as to why such a brilliant idea has not been exploited earlier. This article will attempt to offer some possible explanations to this query, concentrating on both agencies in the production - that of the authorship and that of the audience.

The representation of a supposedly typical Québecois and Anglo character, aspiring to transcend and question the division between French and English Canada, may be seen as reflecting the essential Canadian discourse of the "two solitudes" and its tendency to ignore the so called "third solitude or solitudes" of the indigenous and immigrant "others." However, thanks to the irony present on all levels - in the script, the dialogue, 
(especially in the dialogue), the acting and directing as well as in the images, the film offers the viewer two quite contradictory readings, amounting to what J. Narboni and J-L. Comolli call "progressive text." Therefore, while on one hand, Bon Cop, Bad Cop could be seen as fuelling the separatist discourse in Quebec, on the other, it could effectively be viewed as a biting critique and satirical deconstruction of the said discourse. Given irony's conjunction of the said and that is, its inability to free itself from the discourse it contests the "third meaning" in this dialectical approach emerges, like in any ironic discourse, thanks to what is left "unsaid" - for example in the growing role of the absent "others" in the Quebec society and their otherwise decisive place in the dynamic relationship between events, historical and social context, and public memory. The success of this multi-layered meaning formation is reflected in the box-office, whose record figures could be interpreted as a sign of paradigmatic shift in the Quebec national (-istic) discourse.

Certainly, of utmost importance for the success of the film was the constellation of filmmakers behind the project (most of them Concordia graduates), with good enough bilingual skills and exposure to the complex Quebec-Canada relations, reflected in the language and identity politics from the last two, three decades or so. Another important factor is the excellent timing of the film release, which appeared at the right place and at the right time. Certainly, the decisive role of Kevin Tierney, producer and co-script writer, for the success of Bon Cop, Bad Cop, cannot be stressed enough. Born and raised in Montreal in a working class family of Irish immigrants and fluently bilingual, Tierney was the much needed uniting and balancing force behind the film. His vast experience as a film producer, first for La Fete and then as an independent as a scriptwriter, actor, cinematographer and editor, has earned him a leading place in the Montreal cinéaste world. Without his presence of an outside insider, so to speak, in the almost compactly de souche (or dyed in the wool) Francophone Quebec cinema scene, Bon Cop, Bad Cop would have never materialised so successfully. In any case, it would have most definitely abandoned its multi-layered irony for the sake of a more direct and linear comedy. Tierney's keen eye for the idiosyncrasies of the "two founding solitudes" and his ironic distancing from their ways and mores is almost palpable throughout the film. It is proof of the importance of an outside perspective for the evolution of world cinema. One of the most interesting and sought after Hollywood cameraman, the Hungarian-born Lajos Koltai, once said that directors chose to work with him because of his unexpected visual take on the American reality.

The two layers of meaning of the film - that which invites identification with the explicit antics of the main characters, and that of distancing arising from what is left about the historical and cultural formation of these two diametrically opposite cultural archetypes - "rub together to create the film's intense irony." But, to quote Linda Hutcheon, irony is not an intrinsic quality of the artefact, neither is it "a description of the entity itself but an attribution of a quality of response." Hutcheon goes on to say that "irony is not something in an object that you either "get" or fail to "get": irony "happens" for you (or better, you make it "happen") when the two meanings, one said and the other unsaid, come together, usually with a certain critical edge." Therefore in order to make the irony of the film "happen," there should not only exist an unspoken consensus of what the respective archetypes of the two founding nations are but also a fair amount of desire to "make" the irony and the self-irony "happen" when those archetypes degenerate into stereotypes. In the case of Quebec, the propensity for such self-irony is directly related to the cultural and linguistic confidence acquired over the last couple of decades and the current disappointment with the official separatist policies on the provincial and federal levels.

In his seminal work, The structural Transformation of the Public Sphere, Habermas writes: "Although [in bourgeois democracy] objectively greater demands are placed on [public opinion], the less it operates as a public opinion giving rational foundation to the exercise of political and social authority, and the more it is generated for the purpose of an abstract vote that amounts to no more than an act of acclamation within a public sphere temporarily manufactured for show of manipulation." In other words, "the public" created in election time by technicians of public opinion and Party mobilizers, when left alone for a longer period of time, begs to differ and tends to express its true feelings in a rather unexpected way, like laughing heartily at the irreverent humour offered by Bon Cop, Bad Cop... In this line of thought the success of the film in Quebec could be read as an informal vote on how out-of-date the separatist agenda seem in the eyes of a huge number of people. One cannot but recall one of Marx's most quoted statements from The Eighteenth Brumaire: "All great incidents and individuals in world history occur, as it were, twice: ...the first time as tragedy, the second as farce." In this line of thought, however, the film also testifies to another, more 
powerful sentiment - that of nostalgia for a way of life and cultural mores that are fast disappearing, being as quickly replaced by new ones.

This tendency has been very keenly described by Josh Freed, the famous columnist for The Gazette and script-writer of the 1992 NFB documentary on the state of cultural identity in Quebec, called Between Solitudes. He, too, belongs to the breed of the outsiders, a self-described Jewish protestant on account of the fact that in his time, Jewish kids were sent to the Montreal Protestant school board since the Catholics refused to take them in. In his Gazette column of August 5, 2006, he writes: "If you want to experience the wacky, chaotic Quebec you have always hated to love, then don't look out your front door because it is getting harder to find it there. Instead, go see a new bilingual local film called Bon Cop, Bad Cop, where the outrageous but lovable Quebec of old still thrives"... "And," he continues "as I watched the film, I found myself missing the free-wheeling province it portrayed. In the three years since producers started working on the film, Quebec has been changing from the bad boy of Canada into a virtual Boy Scout."

Indeed, there is a great dose of nostalgia interwoven in the film's irony induced by its makers, and invested by the audience. According to Linda Hutcheon, "in general cultural commentary in the mass media - as in the academy - irony and nostalgia are both seen as key components of contemporary post-modern culture." The power of nostalgia, to quote her again, also lies in its structural doubling-up, not of the said and the unsaid, but of two different times, a present that is found wanting and an idealized past. Nostalgia however is by definition conservative, retrograde, and its mythological symbol is the perennial lament of Lorelei, staring back to the disappearing shores of her homeland.

Perhaps the most eloquent acknowledgement that things have changed irreversibly is found in Josée Blanchette's open letter to Patrick Huard, published in Le Devoir from September 22, 2006. There she attacks the retrograde nostalgic type of masculinity Huard represents and which the majority of Québecois women still adore, dreaming, as she says, "to steal just a kiss from him": Writes Blanchette: "You have personified well in your film the traditional guy, the non-conformist and the rebel; you have painted in broad strokes his modern apparition (daddy cool who shares a duplex with his ex and has the guts to tell her that she is still good for it as she has beautiful breasts), you embody the bad boy dream, the Marlboro man...the alpha male in all of his delinquent splendour... and you do everything to prove this to your Torontonian 'bon cop' ... metro sexual and virile, a man of few words and a great sensibility, who knows how to cook, to care for and charm a woman... My true dream, that is Colm Feore ... for he, unlike you, does not have to put on a permanent display the sub-products of his virility. He just implies them subtly, and this is enough for us... The symbols of your virility (the cigarettes, the alcohol, the cars, the sport) are on the wane, except for the sport. And your type of masculinity is on the wane as well..."

Not unlike Blanchette, Bouchard's ex-wife in the film is also smitten by the gentleman-like behaviour of Ward, which provokes Bouchard's proverbial Gallic jealousy ("since when it is that you speak English?" he retorts). Ward"s lovely sister, however, takes the sexy Quebecker straight to her bed. But this obvious sexual victory over the Anglo other is again internally deconstructed, deceiving and misplacing the expectations, associated with stereotypical utterances and situations, and even the obligatory sex scene is done with an ironic twist. At the climactic moment the sister rhythmically and irreverently moans "Vive le Québec libre! Vive le Québec libre!" The very fact that the audiences in Quebec took this blatant desecration of their patriotic history lightly and with a hearty dose of laughter is the surest sign that the times they are a-changing. As Josh Freed has observed, "politically, things are more subdued here, too. ... Language crazies on both sides have vanished from sight, while noisy sovereignist rhetoric has gone underground because no one wants to hear it. Promising a referendum today seems about as popular as calling for a province-wide colonoscopy."

But why did the film not work in the rest of Canada as well as in Quebec? The easy answer would be for the same reasons it worked in Quebec, since the two solitudes seem to be out of sync culturally. Even the macabre, and somewhat brainy plot-line, implicating a ruthless serial killer who targets NHL officials as a reprisal for selling out to the US, has failed to attract en masse viewers from English Canada, although it seems to be included, in my view, for the sole reason of establishing what all Canadians really feel passionate about. Neither could Rick Mercer's hilarious impersonation of Don Cherry make the expected furor. The viewers from the Rest of Canada seem to have also remained unimpressed by the film's sharp political and cultural satire, not even by the spontaneity of the Ward-Bouchard duo. Perhaps for English Canadians, the 
cultural other they identify themselves against are not the Québecois but first and foremost, the Americans, then the indigenous people and certainly - the newly-arrived-immigrants. Therefore a film about three cops - two Canadians (a Québecois and an Anglo) and an American would most likely work better. I should probably sell this idea to Kevin for the upcoming TV series.

\section{Author Information}

Christina STOJANOVA teaches at the Department of Media Production and Studies at the University of Regina, Canada. She has contributed to Cine-bulles, KinoKultura, and the Montreal Gazette. Her publications include chapters in Berlin Culturescapes, Making it Like a Man: Canadian Masculinities, Eastern European Cinema, Traditions in World Cinema, Horror International, Alternative Europe and Cinema and Globalization. 